\title{
China in the contemporary world order: grand strategy, military modernization, and balance of power ${ }^{1}$
}

\author{
China y el orden mundial contemporáneo: gran \\ estrategia, modernización militar y equilibrio de poder
}

\section{China na ordem mundial contemporânea: grande estratégia, modernização militar e equilíbrio de poder}

\author{
iD@Augusto W. M. Teixeira Júnior \\ Universidade Federal da Paraíba, João Pessoa, Paraíba, Brazil \\ augustoteixeirajr@gmail.com. \\ iD Peterson Ferreira da Silva \\ Escola Superior de Guerra, Brasília, Federal District, Brazil \\ petersonfsilva@gmail.com.
}

\begin{abstract}
The aim of this paper is to analyze the military determinants of China's strategic posture at the beginning of the 21 st century, especially after the wide-ranging military reform introduced by Xi Jinping in 2015 . China has faced major challenges in combining military modernization and Peaceful Development in a strategic environment marked by the balance of power logic. In this context, this paper points out the importance of military modernization for China's grand strategy, even if it means the risk of growing tensions with regional and global military powers.
\end{abstract}

Keywords: China. Asia-Pacific. Grand strategy. Military modernization. Balance of power.

1 The views and opinions expressed in this paper are those of the authors and do not necessarily reflect the official policy or position of any agency of the Brazilian government. 
Resumen: El objetivo de este artículo es analizar los factores condicionantes geopolíticos de la postura estratégica de China a principios del siglo XXI, especialmente después de la extensa reforma militar iniciada en 2015 por Xi Jinping. China ha enfrentado grandes desafíos para combinar la modernización militar y el desarrollo pacífico en un entorno estratégico marcado por el equilibrio de poder. En ese contexto, este artículo señala la importancia de la modernización militar para la gran estrategia china, mismo si eso implique el riesgo de un aumento de las tensiones con las potencias militares regionales y mundiales.

Palabras clave: China. Asia-Pacífico. Gran estrategia. Modernización militar. Equilibrio de poder.

Resumo: O objetivo deste trabalho é analisar os condicionantes militares da postura estratégica da China neste início de século XXI, especialmente após a ampla reforma militar iniciada em 2015 por Xi Jinping. A China tem enfrentado desafios importantes para combinar modernização militar e desenvolvimento pacífico em um ambiente estratégico marcado pela lógica balança de poder. Nesse contexto, este artigo aponta a importância da modernização militar para a grande estratégia chinesa, mesmo que isso signifique o risco de crescentes tensões com potências militares regionais e globais.

Palavras-Chave: China. Ásia-Pacífico. Grande estratégia. Modernização militar. Equilíbrio de poder.

Data de recebimento do artigo: 26/02/2019

Data de aprovação do artigo: 21/05/2019 
China in the contemporary world order: grand strategy, military modernization... Augusto W. M. Teixeira Júnior • Peterson Ferreira da Silva

\section{Introduction}

With an increasingly relevant role on the international stage, China is not only a power house in the global economy, but is also a key actor in the changing contemporary global order. Despite the country's global role and importance in Asia-Pacific, China is working strongly to remake the regional order. China is situated in a region with significant challenges, such as the desired reunification with Taiwan, a nuclear North Korea, the territorial disputes in the South China Sea, and the clashes of interests and perceptions between countries such as the United States, Japan, India, Russia, and Australia.

Even though the balance of power plays a sensitive role in foreign relations in the Asia-Pacific, China's rationale is oriented to a more structural and long-range perspective. Beijing possesses a grand strategy ${ }^{2}$ that explains not only its outstanding development achievements, but also its military build-up. Holding the world's second-largest economy, China has invested approximately 1.9 percent of its GDP in defense (TIAN et al., 2018) and, since 2015 reforms, appears to have embraced a commitment to developing a world-class military by 2050. In accordance with its grand strategy, China is shifting focus from a traditional land power orientation to becoming a new emerging sea power in the 21th century. With strong political guidance from the Chinese Communist Party, the Chinese military is innovating not only in terms of technology and weapons systems, but also in operational concepts and doctrine. In search of a deeper understanding of these changes, this paper sheds light on China's Military Strategy (2015) and its military developments. Aside from the economic and financial importance of China, the country perceives military force as having a fundamental role in its grand strategy.

$\overline{2 \text { Buzan (2014, p. 385) }}$ defines grand strategy as follows: "The basic concept of grand strategy is quite straightforward. It is about articulating a set of core aims, or ends, that define the national interest in terms of both domestic goals and how state and society are to relate to the wider world, and relating those ends to the means that the state and society has available." 
China in the contemporary world order: grand strategy, military modernization... Augusto W. M. Teixeira Júnior • Peterson Ferreira da Silva

This paper joins the debate about the place of military modernization in China's grand strategy, especially after Xi Jinping's 2015 military reform. The first part introduces the role of military force in China's grand strategy in recent years. The second section briefly discusses the military dimension of Peaceful Development, ${ }^{3}$ including the background of the challenges concerning stability in China's political system. Finally, the main tensions and contenders of Chinese grand strategy are analyzed, with a focus on the AsiaPacific balance of power.

\section{The role of military force in China's grand strategy}

China's economic growth over recent decades has occurred in the context of greater relevance for emerging countries in the delineation of the international order. This perception has gained more prominence especially with the appearance in 2001 of the acronym BRICs (Brazil, Russia, India and China - South Africa was later incorporated into the group). China and India, in particular, have played increasing roles on the international arena in recent decades, in contrast to the questionable results obtained in the latest years by Brazil and Russia, which were below expectations (MCLANNAHAN, 2015; MCRAE, 2018). According to economists, about 70 percent of global growth over the next 12 years is expected to come from emerging markets, with the possibility of China occupying the position of the world's largest economy by 2030, surpassing the United States. India, for its part, may occupy third position, surpassing countries like Japan, Germany, the United Kingdom, and France (MCRAE, 2018). According to the World Bank, Chinese GDP grew annually above double digits between 2003 and

\footnotetext{
3 The White Paper on China's Peaceful Development was first published in 2011. Celebrating the 90th anniversary of the foundation of the Chinese Communist Party, the Paper presents the Chinese views on the following contents: “I. The Path of China's Peaceful Development: What It Is About; II. What China Aims to Achieve by Pursuing Peaceful Development; III. China's Foreign Policies for Pursuing Peaceful Development; IV. China's Path of Peaceful Development Is a Choice Necessitated by History; V. What China's Peaceful Development Means to the Rest of the World". In alignment with authors such as Buzan (2014), we consider the White Paper on China's Peaceful Development as the country's grand strategy.
} 
China in the contemporary world order: grand strategy, military modernization... Augusto W. M. Teixeira Júnior • Peterson Ferreira da Silva

2007. In addition, even considering the effects of the 2008 crisis on the global economy, during the first three months of 2015, for example, only three countries (China, USA, and India) accounted for approximately 80 percent of global economic growth (ECONOMIC and financial..., 2015).

In 2013, Xi Jinping was appointed president of the People's Republic of China (PRC) by the National People's Congress, succeeding Hu Jintao (2003-2013). Since the beginning of his administration, $\mathrm{Xi}$ Jinping has put in place a series of economic and social reforms in the country (KROEBER, 2013; YAO; BLANCHARD, 2013). Considered by analysts as the most ambitious since Deng Xiaoping (1978-1990), these broad reforms can be viewed, in few words, as an attempt to solidify expectations about the continuity of Chinese economic growth within an international scenario shaken by the 2008 financial crisis. The first signs of Xi Jinping's intention to expand these reforms to the country's military field became evident in 2014 when public information was released regarding a working group under the direct leadership of Xi Jinping with the objective of "building a strong army" (BLANCHARD, 2014; CHINESE army to raise ..., 2014; SAUNDERS; WUTHNOW, 2016, p. 9).

Although China is mainly known for its fast-growing economy and its outstanding development performance, the deep changes that are on the way are strongly tied to a grand strategy, broader than the more visible economic and trade areas (BUZAN, 2014). During the $19^{\text {th }}$ Congress of the Communist Party, the general interpretation and guidance for China's future was clearly highlighted by president Xi Jinping (2017). The "Chinese dream of national rejuvenation" is both an idea and a guiding principle that combines distinct expressions of Chinese national power and affairs toward a desired future. The country's grand strategy, like other great powers before it, upholds the strategic importance of globalization, in- 
China in the contemporary world order: grand strategy, military modernization... Augusto W. M. Teixeira Júnior • Peterson Ferreira da Silva

terdependence, and the relevance of military power as pillars for a Peaceful Development. ${ }^{4}$

But how can China make sense of its ideal of Peaceful Development when at the same time it is going through one of the most rapid military modernization processes in recent history? A document that helps to understand the Chinese grand strategy, specially its military dimension, is the Chinese Defense White Paper, also known as China's Military Strategy (2015). Launched in May 2015, it gives attention to the military modernization of the People's Liberation Army (PLA). ${ }^{5}$ As a document about strategy, it draws on perceptions about the regional and global balance of power and how the Chinese Communist Party and the Ministry of National Defense (MND) will answer the challenge of modernizing the military. By analyzing China's Military Strategy (2015), it is possible to uncover some traces of the country's grand strategy, in which, increasingly, the military component is made explicit. Officially, the Strategy aims to support Chinese Peaceful Development. It sustains that it is an instrument to pursue an independent and peaceful foreign policy and national defense with a defensive orientation.

Seeking coherence with Chinese strategic identity (ROMANA, 2016), the document is strongly linked with ideas deeply rooted in Chinese military thought, such as People's War, anti-hegemonism, and power politics ${ }^{6}$. It is important to stress that for China, military power and national development are key to Peaceful Development.

\footnotetext{
4 China's path to peaceful development can be describe as follows: "China should develop itself through upholding world peace and contribute to world peace through its own development. It should achieve development with its own efforts and by carrying out reform and innovation; at the same time, it should open itself to the outside and learn from other countries. It should seek mutual benefit and common development with other countries in keeping with the trend of economic globalization, and it should work together with other countries to build a harmonious world of durable peace and common prosperity. This is a path of scientific, independent, open, peaceful, cooperative and common development." (CHINA, 2011, online).

5 The PLA consists of five military services: PLA Army/ Ground Force, PLA Navy, PLA Air Force, Rocket Force and Strategic Support Force, with support of Armed Police Force and Reserve Force. Source: Ministry of National Defense - Military Services. Available in: http://eng.mod.gov.cn/services/index.htm.

6 As would be expected of a grand strategy, the White Paper on China's Peaceful Development echoes the same principles and objectives. The document states that: "China is committed to pursuing a defense policy which is defensive in nature. China has a vast land territory and sea area, with a borderline of over 22,000 kilometers and a coastline of over 18,000 kilometers. China faces multiple traditional and non-traditional security challenges and the threat of separatists and terrorism. It is therefore necessary and justified to modernize China's defense capabilities in order to uphold China's security and protect its peaceful development. The fundamental purpose of modernizing the Chinese armed forces is to safeguard China's sovereignty, security, territorial integrity and interests of national development. China's defense expenditures are appropriate and moderate, and are in keeping with the need to safeguard its security. China will not engage in arms race with any other country, and it does not pose a military threat to any other country. China follows the principle of not attacking others unless it is attacked, and it is committed to solving international disputes and hotspot issues with peaceful means. China actively carries out international military exchanges, promotes international and regional security cooperation and opposes terrorism in all forms." (CHINA, 2011, online).
} 
China in the contemporary world order: grand strategy, military modernization... Augusto W. M. Teixeira Júnior • Peterson Ferreira da Silva

In that sense, the People's Liberation Army is understood as instrumental to political objectives, such as the maintenance of peace and regional and domestic stability. In accordance with China's defensive strategic posture, the Strategy affirms clearly that the country will never seek hegemony or expansionism (CHINA, 2015).

Despite valuing a peaceful rise, China's grand strategy encompasses the centrality of military modernization in the country's international insertion approach. As president Xi Jinping (2017) stated, it is vital that Chinese military power be upgraded in order to support the grand strategy, helping to fulfill the "Chinese dream of national rejuvenation". In this regard, the "Two Centenaries" are particularly important. The first (1921 - 2021) marks the 100-year anniversary of the foundation of the Chinese Communist Party and the second (1949 - 2049) celebrates the first century of the Chinese Revolution. The strong relation between grand strategy goals and military modernization is also stated in China's Military Strategy (2015). Although it celebrates the historical conquests of the Chinese People, the Two Centenaries also provides parameters of time and objectives that holds together grand strategy and military modernization. ${ }^{7}$

Even though military power has an important place in China's grand strategy, it is understood as a part of national power. ${ }^{8}$ China sees itself as linked to the world order and economy, and this interdependency is viewed as key to supporting the country's development process. For that, peace, prosperity, and above all, stability are concepts that emerge in Beijing's rhetoric as fundamental to its Peaceful Development. In official documents such as China's Military Strategy (2015), global trends intensified by the expansion of the information society, mainly multipolarity and economic glo-

\footnotetext{
7 The White Paper on China's Peaceful Development helps to make the historical meaning of both years clear. As quoted: "In the mid-19th century, Western powers forced open China's door with gunboats. Internal turmoil and foreign aggression gradually turned China into a semi-colonial and semi-feudal society. The country became poor and weak, and the people suffered from wars and chaos. Facing imminent danger of national subjugation, one generation of patriots after another fought hard to find a way to reform and save the nation. The Revolution of 1911 put an end to the system of monarchy which had ruled China for several thousand years, and inspired the Chinese people to struggle for independence and prosperity. However, such efforts and struggle failed to change the nature of China as a semi-colonial and semi-feudal society, or lift the Chinese people out of misery. Living up to the people's expectation, the CPC led them in carrying out arduous struggle, and finally founded the People's Republic of China in 1949. This marked the realization of China's independence and liberation of its people and ushered in a new epoch in China's history." (CHINA, 2011, online).

8 To read more about China's Comprehensive national Power, see Teixeira Júnior, Sousa and Leite (2017).
} 
China in the contemporary world order: grand strategy, military modernization... Augusto W. M. Teixeira Júnior • Peterson Ferreira da Silva

balization, are positive forces to the consolidation of China's position as a rising great power. But while interdependence may by a positive force in favor of Chinese goals, other profound changes in world politics threat to upset Beijing's peaceful rise. Factors such as changes in the balance of power, which affect the global governance and the geostrategic environment in Asia and the Pacific, are contemporary trends that raise challenges to China's grand strategy. Moreover, international competition occurs in different spheres, in fields such as economy, trade, science and technology, and military (CHINA, 2015).

In a world of increasing competition between powers, China strives to keep gaining peace dividends in an age of contested economic globalization. ${ }^{9}$ In its grand strategy view, peaceful discourse and a predominant defensive posture are supported by its Comprehensive National Power. A future view and strategy are leading Beijing into building foundations for both resilience and influence in a multipolar $21^{\text {th }}$ century. For China, development and national security are two sides of the same coin. In the domestic arena, social and political stability are strongly related to the success of economic development and improving the life quality of its citizens. In a certain way, the legitimacy of the Communist Party depends on it. In the international arena, "China has an arduous task to safeguard its national unification, territorial integrity and development interests." (CHINA, 2015, online). The Chinese Military Strategy (2015) is clear about the challenge posed by the protection of Chinese rights and the need to maintain stability along its periphery. As one of the expressions of national power, military power is fundamental not just to attend objectives of China's grand strategy, but also is part of the country's national development process. Above all, military modernization is understood by the coun-

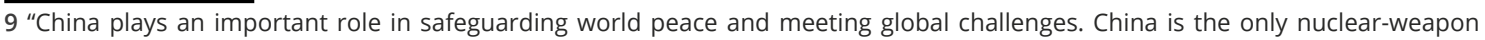
country that has publicly stated that it will not be the first to use nuclear weapons, or use or threaten to use nuclear weapons against non-nuclear-weapon states or nuclear-weapon-free zones. China has dispatched about 21,000 personnel on 30 UN peacekeeping missions, which is the highest number among the permanent members of the UN Security Council. China takes an active part in international cooperation in anti-terrorism and nonproliferation. It provides humanitarian aid and dispatches rescue teams to countries hit by severe natural disasters and deploys naval escort fleets to combat piracy in the Gulf of Aden and off the coast of Somalia." (CHINA, 2011, online). 
China in the contemporary world order: grand strategy, military modernization... Augusto W. M. Teixeira Júnior • Peterson Ferreira da Silva

try as an enabler for reassuring China's position in Asia-Pacific, in response to the "Century of Humiliation"10 (JINPING, 2017).

\section{The military dimension of Peaceful Development: China's military modernization}

China is a country that see itself under constant threat. Since 1949, with the end of the Revolutionary War, the Central Military Commission $(\mathrm{CMC})^{11}$ has established and revised successive versions of Military Strategic Guidelines (MSG), ${ }^{12}$ which underwent significant changes since the 1980s and especially after the Cold War.

In the wave of modernizations and reforms led by president Deng Xioping (1978-1990), the role of the Revolutionary War in the shaping of Chinese military strategy lost significant ground. With the launch of "People's war under modern conditions" doctrine, the idea of prolonged war lost its centrality (JOFFE, 1987). With this, the emphasis on total warfare has given way to a focus on limited warfare. Another important aspect was the gradual change of emphasis, related to which military domains should be prioritized by the People's Liberation Army (PLA). Traditionally centered on the ground component of the PLA, from the 1980s China slowly moved to a military profile that prioritizes air power, naval power, and the missile capabilities (IISS, 2018; JINPING, 2017; SINGH, 2016).

With the end of the Bipolar World Order and in the context of the Chinese evaluation of the technological repercussions of the I Gulf War (1990-1991) (LIANG \& XIANGSUI, 1999), ${ }^{13}$ two concepts clearly expose what the Chinese call "preparation for military

\footnotetext{
10 The political use of the idea of the "Century of Humiliation" was strongly developed by president Jiang Zemin. It uses the harsh history of the $19^{\text {th }}$ and pre-revolutionary China as a call for national pride and unity. See Zemin (1997). According to Singh (2016), Chinese nationalism is inspiring defense and armed forces modernizations, strongly connected with Beijing's Grand Strategy.

11 "The Central Military Commission (CMC) takes charge of the overall administration of China's armed forces. It has 15 functional sections including seven departments (offices), three commissions and five directly affiliated bodies". Source: Ministry of National Defense - CMC. Available in: http://eng.mod.gov.cn/cmc/index.htm.

12 According to Singh (2016), MSG are similar to the U.S. National Military Strategy.

13 One of the major works illustrating the lessons learned by China from the American experience in the I Gulf War and Revolution in Military Affairs is the book "Unrestricted Warfare" (LIANG \& XIANGSUI, 1999).
} 
China in the contemporary world order: grand strategy, military modernization... Augusto W. M. Teixeira Júnior • Peterson Ferreira da Silva

struggle" (PMS). ${ }^{14}$ The first operational concept, launched in 1993, "winning local wars in the conditions of modern technology," was the first post-Cold War PMS to incorporate the hypothesis of local wars in which the centrality of the principle of mass begins to lose space to technology. Despite all the difficulties (CHASE et al., 2015; SLOAN, 2008), ${ }^{15}$ it is during this period that the country starts giving more emphasis to professionalism and technology, while gradually reducing the political roles of the People's Liberation Army ${ }^{16}$ (SINGH, 2016; WUTHNOW \& SAUNDERS, 2017). The second operational concept, "winning local wars under conditions of informationization", created in 2004, expresses the preparation for military struggle incorporating the informational dimension and the Western debate on military technology and Revolution of Military Affairs (RMA) (SLOAN, 2008).

The 2015 Military Strategy also refers to Revolution in Military Affairs (RMA) as a reference for Western military change to which Chinese modernization reacts. The document states that the RMA would be reaching a new stage, marked by more sophisticated equipment, with emphasis on long-range, precision, intelligent, stealth, and unmanned weapons systems. Among the changes foreseen in the operational doctrines are the adhesion to principles of flexibility, mobility, and "independence". ${ }^{17}$ Other important features of the debate concerning RMA and Military Transformation in the West are seen more often in Chinese strategic and doctrinal design.

\footnotetext{
14 According to China's Military Strategy (2015), PMS is a basic military practice, aimed at securing peace, containing crises, and winning wars. The choice of the term "struggle" incorporates a conception that transcends the participation of the military element in the more general context of the warlike activity. According to a strategic culture based on the popular war effort, the war incorporates the dimensions of government, people, and their military institutions in their dynamics (SINGH, 2016).

15 In his classic on Military Transformation, Sloan (2008) looks at China's transformation efforts between the 1990s and the first half of the 2000s. In a study published by Rand Corporation, Chase et. al. (2015) presented an in-depth analysis of the transformation challenges of the People's Liberation Army (PLA). The Military Balance (IISS, 2018), for example, points out several corrections and adjustments in the direction of the Chinese military transformation, emphasizing the conversion of the Chinese military profile to a strength based on technology, to the detriment of the emphasis in the quantitative of personnel and equipment.

16 It should be noted that the articulation between great strategy and military power is fundamentally engineered through the subordination of the military to the civil power represented in the Communist Party and the President of China. The articulation of civil-military relations in China has recently been reinforced in the text of the defense reforms led by President Xi Jinping (JINPING, 2017, WUTHNOW \& SANDERS, 2017). Concomitant with the above-mentioned political-military concertation, the perception of security challenges to Chinese interests is widened, further narrowing the relationship between development and security so important in the scope of its grand strategy.

17 The Chinese understanding of this component is summed up in the expression "you fight your way and I fight my way". In other words, it supports the ability of each unit or large unit to fight independently and be self-sustaining at tactical or theater levels.
} 
China in the contemporary world order: grand strategy, military modernization... Augusto W. M. Teixeira Júnior • Peterson Ferreira da Silva

It is important to note that the changes in the doctrinal field mentioned above are directly linked to changes in China's geostrategic environment. That said the Central Military Commission (CMC) and the Communist Party has the perception that the pace of modernization has to be accelerated. Just as the United States acknowledges, China also perceives the erosion of the Western technological advantage and superiority (CHINA, 2015). Since the end of the Cold War, the US has had the privilege of being able to deploy forces and maneuver in almost every theater of operation in which it wished to operate. Today, this capacity is threatened by the proliferation of technologies previously restricted to a few Powers, such as the combination of old and new military means. In sum, it is possible to affirm that, in this new phase of modernization, China perceives great powers adjusting their strategies of national security. As a result of this process, defense policies and military expenditures are oriented to the restructuring of its armed forces and transformation, with emphasis on the cybernetic and space domains (CHINA, 2015). The preparation for military struggle linked to the doctrine of winning local wars under conditions of informationization demands in its planning organizational changes (structures and institutions promoting interoperability), development of means and doctrines to face threats of new domains (new operational concepts and systems), and modular forces suitable for use in the broad spectrum of operations.

In China's Military Strategy 2015, to implement the "Strategic Guideline of Active Defense", aspects of the "preparation for military struggle" needed to be changed. The modifications pointed out in the doctrinal review in 2004 are deepened in 2015 in order not only to guide military preparation for the informational dimension of warfare, but also to develop PMS for the maritime domain. ${ }^{18}$ With the presidency of Xi Jinping, the PLA Navy becomes a basic element of the country's grand strategy. Maritime power, its naval component, becomes central to China's national secu-

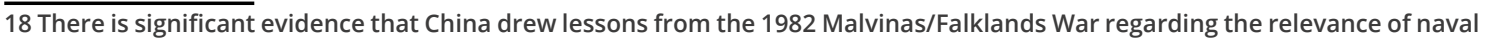
power and air components to limited offensive military operations (SINGH, 2016). 
China in the contemporary world order: grand strategy, military modernization... Augusto W. M. Teixeira Júnior • Peterson Ferreira da Silva

rity and defense of its development interests. ${ }^{19}$ Other objectives linking the projection to the sea are the guarantee of sovereignty and Chinese rights and interests, such as the safety of Sea Lines of Communications (SLOCS) and overseas interests. This concern is evident as we recall the growing relevance of Chinese off-area operations in the Indian Ocean and Gulf of Aden (IISS, 2018; SILVA \& TEIXEIRA JÚNIOR, 2016). In this direction, the 2015 Military Strategy clearly states that the "traditional mentality that land outweighs must be abandoned, and great importance has been attached to managing the seas and oceans and protecting maritime rights and interests" (CHINA, 2015, online). Not only did the Navy of the People's Liberation Army gain space in the PMS, the move towards "blue waters" affected missions and changed operational concepts. Furthermore, China is also gradually shifting from "coastal waters defense" to combining this with its "open seas protection" mission (CHINA, 2015).

The sum of these transformations imposes on traditional powers the "challenge of access", represented by the American debate on Anti-access/Area-Denial, or A2/AD (TEIXEIRA JÚNIOR, 2018). China perceives and constructs an asymmetric strategy as opposed to the strategy of its contenders (CLIFF, 2011). Technological innovations that illustrate these arguments can be seen, for example, in the air and maritime domain. In the air, the development of PL-15 air-to-air missiles allows China to contest the air dominance of opponents (IISS, 2018). At sea, Type-055 class cruisers point to China's rapid advance in blue water capabilities suitable for both actions in the field of denial of area and maritime access and power projection (IISS, 2018).

According to the International Institute for Strategic Studies (IISS), as listed at the 19th Congress of the Chinese Communist Party, the country may have reached the first phase of modernization until 2021. This phase is characterized by the mixture between mechanization and computerization of its armed forces (IISS, 2018, p. 225). With this military modernization, a Chinese version of

19 On the "rediscovery" of Alfred T. Mahan's thought in China, see Sempa (2014). On the current state of Chinese naval production, see for example IISS (2018). 
China in the contemporary world order: grand strategy, military modernization... Augusto W. M. Teixeira Júnior • Peterson Ferreira da Silva

Network Centric Warfare (NCW) therefore become possible. In addition, China's Military Strategy (2015) considers that:

China's armed forces will quicken their steps to transform the generating mode of combat effectiveness, work to use information systems to integrate a wide range of operational forces, modules and elements into overall operational capacity, and gradually establish an integrated joint operational system in which all elements are seamlessly linked and various operational platforms perform independently and in coordination. (CHINA, 2015, online).

In practice, Xi Jinping's military reform already indicates some significant results. The China Military News Agency (2017), for example, highlighted the following points: (i) the four general departments at military headquarters were reorganized into 15 agencies within the Central Military Commission (CMC) and one-third of the personnel were cut; (ii) five Joint Theater Commands were established to replace the previous seven traditional Military Area Commands; (iii) a new military structure has been established with the CMC exercising overall leadership, while the theater commands are responsible for military operations and the services focus on developing capabilities; (iv) after remarkable downsizing, the Ground Forces (PLA Army) now accounts for less than 50 percent of the armed forces; ( $v$ ) over one thousand units at the regiment level or above and 30 percent of commissioned officers were cut during the reform; (vi) seventy-seven military education institutions were regrouped to forty-three, including a strengthened National University of Defense Technology; and (vii) new laws and regulations on military issues have been introduced or amended, including a revised regulation on civilian personnel in the military released on Nov. 10, 2017 (FACTS and figures..., 2017).

Notwithstanding the relevance of technology in the present debate, Chinese modernization is guided by policy, ${ }^{20}$ in this case, by the national strategic objective, on which the Strategy is clear:

20 "The Chinese military reform proclaimed by Xi is larger in scale and more thorough, especially since it seriously affects the country's domestic policy and is related to problems of stability in China's political system" (KOKOSHIN, 2016, p. 2). 
China in the contemporary world order: grand strategy, military modernization... Augusto W. M. Teixeira Júnior • Peterson Ferreira da Silva

China's national strategic goal is to complete the building of a moderately prosperous society in all respects by 2021 when the CPC celebrates its centenary; and the building of a modern socialist country that is prosperous, strong, democratic, culturally advanced and harmonious by 2049 when the People's Republic of China (PRC) marks its centenary. It is a Chinese Dream of achieving the great rejuvenation of the Chinese nation. The Chinese Dream is to make the country strong. China's armed forces take their dream of making the military strong as part of the Chinese Dream. Without a strong military, a country can be neither safe nor strong. (CHINA, 2015, online).

One of the main forces in the changing of the global order and economic landscape in Asia-Pacific region, China's Peaceful Development may, however, be disturbed. The once stable conditions to Beijing's rise to power are now challenged by regional and extra-regional contenders. Beijing is, day after day, more sensitive to the balance of power, due the strong bond of interdependence between the regional economics, security environment, and conditions for internal growth and development. In a certain way, its reactions towards Western Revolution in Military Affairs and Military Transformation also triggers reactions at the regional and global levels. On that matter, China's Military Strategy (2015) mentions tensions and competitions with countries such as the United States, Japan, The Koreas, Taiwan, and India (SINGH, 2016). In order to understand how the deep changes in China's military power are shaping its own security environment, the next section analyzes the Asia-Pacific's main Balance of Power features.

\section{Tensions and contenders of Chinese grand strategy: the Asian Balance of Power}

Even though its spectacular economic development, China's geography is still a continuous source of security concern (KAPLAN, 
China in the contemporary world order: grand strategy, military modernization... Augusto W. M. Teixeira Júnior • Peterson Ferreira da Silva

2013). As shall be developed below, Chinese borders are still problematic in terms of historical problems and rivalries. In the North, historical tensions with Russia are softened by nowadays conjunctural alignment. Although with reduced tensions with Moscow, China's Northern border keeps Beijing in contact with Mongolia, a "NATO Partner Across the Globe", intensifying China's geostrategic challenges with the United States. Furthermore, the role of the relationship between United States and China regarding regional stability (BRZEZINSKI, 2013; PETHIYAGODA, 2017), as well as China's need to secure energy, raw materials and strategic minerals "in order to support the rising living standards of its immense population" (KAPLAN, 2010, online) are other important geopolitical factors that challenge the notion that geography no longer matters (KAPLAN, 2013).

In its Northwest border, Beijing struggles with the geographic imperative of bordering India, a main regional contender with nuclear capabilities. The perils of strategic competition between India and Pakistan, brings to Beijing the problem of nuclear deterrence and asymmetric balancing. Northwest China is also a place of a cultural border. The conflicts in Xinjiang region are illustrative of both the need of developing deep China, but also of fostering cultural unity. Both issues are crucial to social cohesion and stability by Beijing authorities (KAPLAN, 2013).

As central as the geopolitical trends of China's continental dimension may sound, it is mainly at sea that Chinese $21^{\text {st }}$ century geopolitics is better highlighted. The more China goes global, more it relies on oceans and seas. One of the results of the Chinese rise in Asia-Pacific, mostly through the outstanding increase of Beijing's sea power, is the fact that Japan reemerges at a strategic concern to China (CHINA, 2015). During the last decade, Prime-Minister Abe has been successful in changing the previous interpretation about article 9 of the Japanese constitution, which directly influences how Tokyo understands the relation between war and politics (YOSHIDA, 2018). According to the "The Military Balance 2018" (IISS, 2018), Japan is being influenced by the changing Chinese military profile. 
China in the contemporary world order: grand strategy, military modernization... Augusto W. M. Teixeira Júnior • Peterson Ferreira da Silva

The improvement of Japan's military capabilities and strategic mindset is seen as a possible threat to Chinese maritime interests. No other example displays this better than the Sino Japanese dispute for the Senkaku/Diako islands (see Figure 1). ${ }^{21} \mathrm{~A}$ clear sign of Japan's recent normalization process is the fact its maritime self-defense force is giving support to the country strategy towards China.

Figure 1 - Major Japanese Defense/Coast Guard Facilities in the Southwest Islands

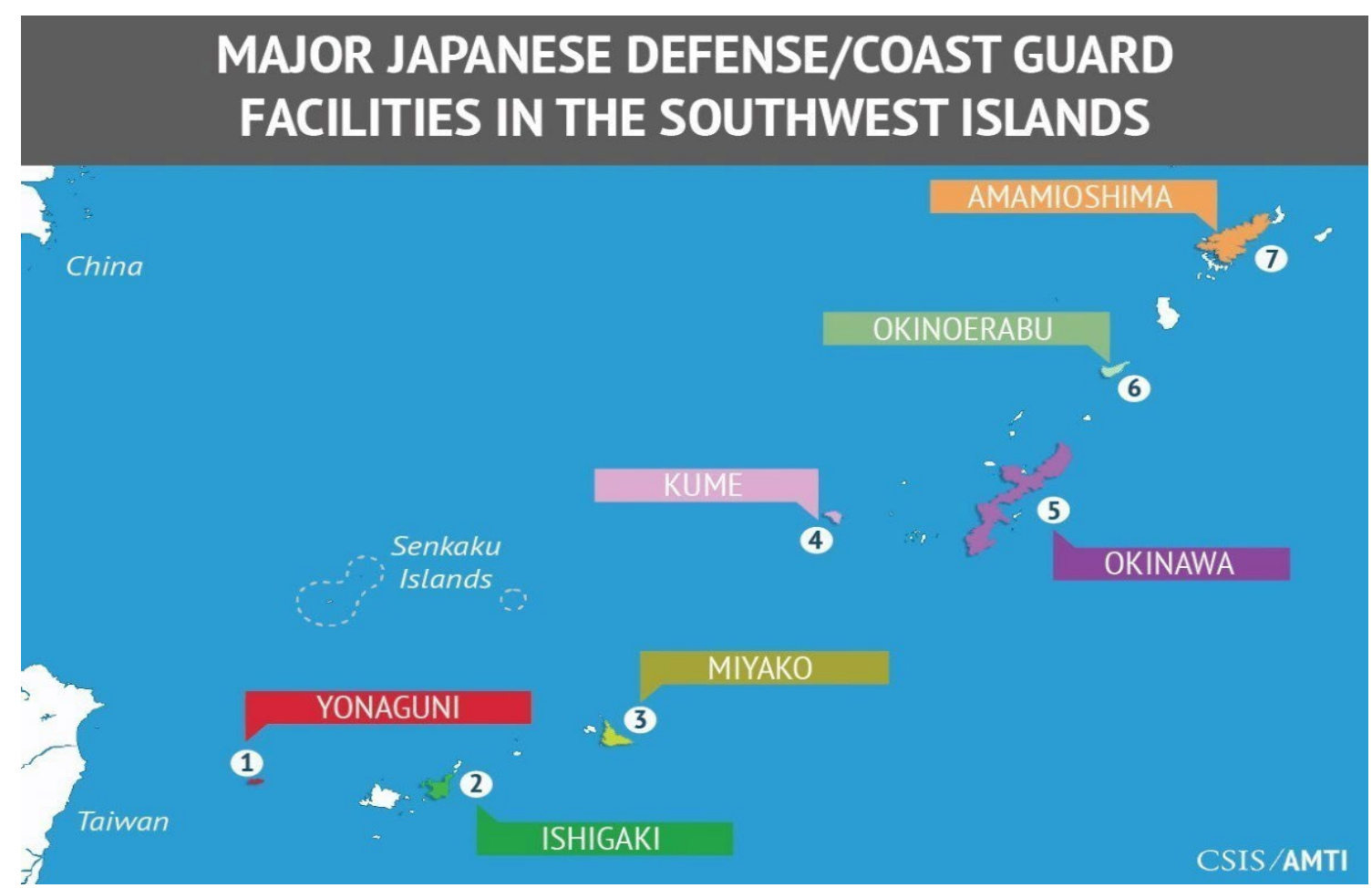

Source: PLAYING Chicken in the East China Sea. Asia Maritime Transparence Initiative, Center for Strategic and International Studies (CSIS). April 28, 2017. Available in: https://amti.csis.org/playing-chicken-east-china-seal. Accesses on: 23 Feb. 2019.

As shown in The Military Balance 2018 (IISS, 2018), Izumo-class helicopter carriers will be upgraded to be able to operate F-35 fighter jets. The same report points out that Izumo-class carriers

21 For a deep analysis of the Senkaku/Diako islands dispute, see: "Playing Chicken in the East China Sea”, Asia Maritime Transparence Initiative, Center for Strategic and International Studies. April 28, 2017. Available in: https://amti.csis.org/playing-chicken-east-china-sea/. 
China in the contemporary world order: grand strategy, military modernization... Augusto W. M. Teixeira Júnior • Peterson Ferreira da Silva

and Japanese destroyers were sent to South China Sea and surroundings. In another sign of Tokyo's defiance, Japanese vessels visited the ports of the Philippines, Singapore, and Vietnam, countries that have maritime disputes with China (IISS, 2018).

The renewed military profile of Japan and its actions in sensitive areas of Chinese interest heightens Beijing preoccupation with control particularly over the South China Sea (see Figure 2). As mentioned in the Chinese Military Strategy (CHINA, 2015), this area, fundamental to Chinese maritime rights and interests, is highly prone to aerial and maritime surveillance and reconnaissance activities against Beijing interests.

Figure 2 - Nine-Dash Line and the South China Sea Conflict

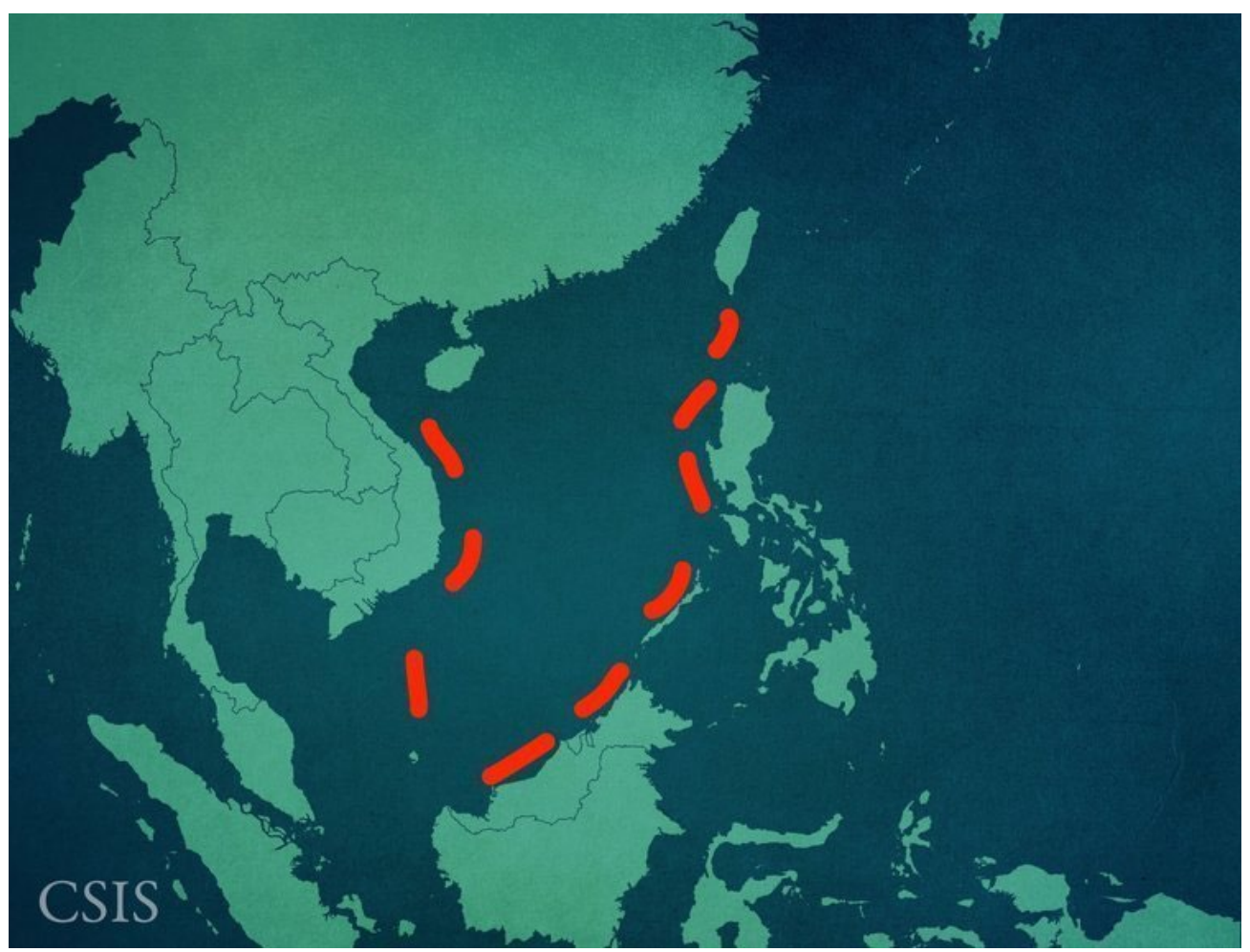

Source: LIU, Zhen. Here's what's behind the 'nine-dash line' that sparked the South China Sea conflict. Business Insider. Jul. 11, 2016. Available in: https://www.businessinsider.com/the-nine-dash-line-at-the-heart-of-the-south-china-sea-conflict-2016-7. Accesses on: 23 Feb. 2019. 
China in the contemporary world order: grand strategy, military modernization... Augusto W. M. Teixeira Júnior • Peterson Ferreira da Silva

According to IISS (2018), for the Chinese Communist Party and the People Liberation Army (PLA), securing the control over South China Sea and its adjacent waters is a strategic priority. In order to accomplish the goal, China is strengthening and expanding its bases and military installations in that area (CHINESE paper urges..., 2013). Product of a political choice of the Chinese Communist Party, the geopolitical transformation towards the Sea highlights the South China Sea as the primary horizon for Chinese expansion not only to open oceans of the Pacific, but also to the narrow corridors and strategic choke points that opens the doors to the Indic Ocean. At Sea, China's historical bond with South China Sea poses the challenge of changing its traditional orientation towards the mainland for a contemporary trend toward a maritime or amphibious geopolitical power.

Directly related to Beijing's grand strategy for geopolitical and economic objectives, such as the Maritime Silk Road, Chinese military presence expands beyond East Asia, putting China's interests on a collision course not only with the United States, but also with India (IISS, 2018). According to the International Institute for Strategic Studies (2018), since the Chinese reorientation towards being a Sea Power in the first decade of the $21^{\text {st }}$ century, the Indian Ocean is turning into a more relevant operational area for the naval and aerial components of the People's Liberation Army (see Figure 3). 
China in the contemporary world order: grand strategy, military modernization... Augusto W. M. Teixeira Júnior • Peterson Ferreira da Silva

\section{Figure 3 - Chinese-US balance}

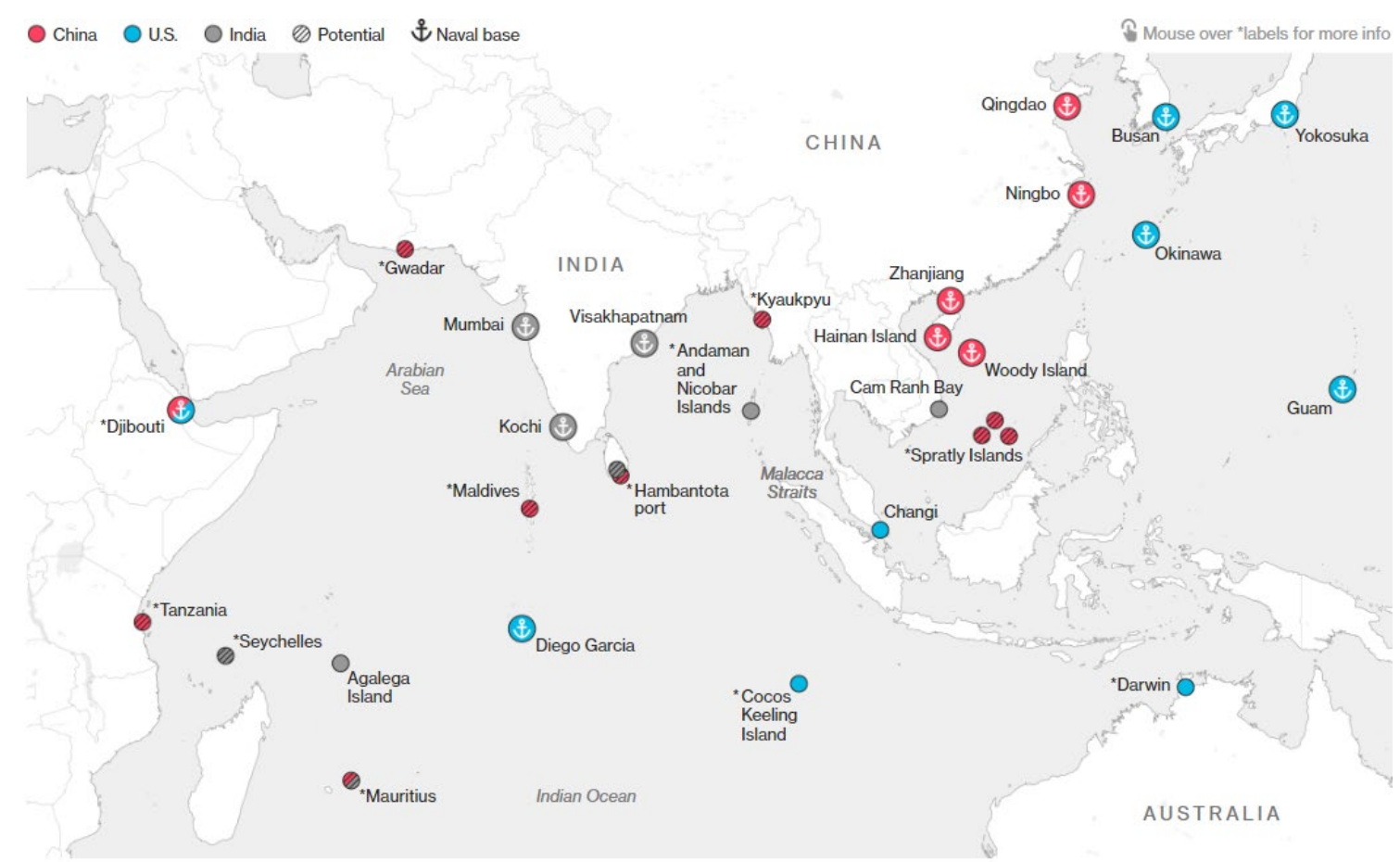

Source: TWEED, David; LEUNG, Adrian. China Is Making a Bold Military Power Play. Bloomberg, May 7, 2018. Available in: https://Www.bloomberg.com/graphics/2018-china-navy-bases/. Accesses on: 23 Feb. 2019.

The Pacific and Indian Ocean are now the main areas of interest of Chinese military power projection. Other examples of Chinese maritime exercises hint at the extension of Beijing's testing of its capabilities into projecting force across long distances, far away from the limits of the Asia-Pacific. As an example, in 2017, China joined the Russian navy in joint exercises in the Baltic Sea (IISS, 2018). Trying to bring balance between the defense of its historical rights and the need to maintain peace and stability, China is searching to broader international cooperation. Beyond the alignment with Russia, China has worked to strengthen its military ties with the Shanghai Cooperation Organization (SCO). ${ }^{22}$ In addition to that, Beijing is making itself more present at multilateral dialogue and cooperation mechanisms in the Asia-Pacific region (IISS, 2018).

\footnotetext{
22 "The Shanghai Cooperation Organisation (SCO) is a permanent intergovernmental international organisation, the creation of which was announced on 15 June 2001 in Shanghai (China) by the Republic of Kazakhstan, the People's Republic of China, the Kyrgyz Republic, the Russian Federation, the Republic of Tajikistan, and the Republic of Uzbekistan. It was preceded by the Shanghai Five mechanism". Source: About SCO. Available in: http://eng.sectsco.org/about_sco/.
} 
China in the contemporary world order: grand strategy, military modernization... Augusto W. M. Teixeira Júnior • Peterson Ferreira da Silva

There is a perception by Beijing authorities that security risks at the Chinese periphery are increasingly growing. If China's grand strategy guides the country towards a more active role in the shaping of the regional order, it also brings onto the table challenges that increase the range of national interests susceptible to national security risks, such as regional turmoil, terrorism, piracy, pandemics, and natural disasters. Above all, Beijing's Strategy stresses the importance of protecting natural resources and energy, and securing maritime lines of communication and that of its personnel and institutions abroad (CHINA, 2015).

Although the undoubtedly importance of South China Sea, Northeast China is still a hot place for security concerns to Beijing. North Korean nuclear proliferation and the maintenance of American Military in South Korea displays an uncomfortable situation to China. Although the Korean Peninsula missile crises threatens to result in war in a country that borders China, the issue of Taiwan's independence is a more perennial point and source of sensitive concern for Chinese national security. As with other security challenges to Chinese Peaceful Development and rise described above, the Taiwan issue hits directly on a key aspect of the "Chinese dream of national rejuvenation": reunification. As mentioned explicitly in the Chinese Military Strategy,

The Taiwan issue bears on China's reunification and long-term development, and reunification is an inevitable trend in the course of national rejuvenation. In recent years, cross-Taiwan Straits relations have sustained a sound momentum of peaceful development, but the root cause of instability has not yet been removed, and the "Taiwan independence" separatist forces and their activities are still the biggest threat to the peaceful development of cross-Straits relations. (CHINA, 2015, online).

Not only the United States holds its ground in continental Northeast Asia, as it still challenges Chinese dream of unification with Taiwan (KAPLAN, 2013). Aside from the challenges posed by 
China in the contemporary world order: grand strategy, military modernization... Augusto W. M. Teixeira Júnior • Peterson Ferreira da Silva

the United States, Japan, and other countries of the South China Sea, perils and tensions within the Chinese periphery also have the chance to affecting security and undermine Beijing's Grand Strategy. Regardless of the fact that Chinese leadership does not think a great war is probable in the short-term, Beijing sees as plausible the outbreak of small-scale wars in some regions of the world. Apart from what the China Strategy (2015) sees as smallwars, the document also mentions "new threats", such as hegemonism, power politics, and neo-interventionism as sources of concern. Although is not stated directly, a close analysis of the China's Military Strategy (2015) allows the understanding that the main source of the so-called "new threats" is the United States, especially with regard to the U.S. military presence on the Taiwan Strait and Korean Peninsula.

Despite the intensity of the debate about a future war between China and the United States in recent years (ALLISON, 2017; MEARSHEIMER, 2014), there is skepticism about China seeking armed conflict with the US. Beijing's preference regarding the United States would be in favor of seeking peaceful relations. To oppose the United States in military terms would imply an undermining of the international order; the same structures that benefit China. That said, a Sino American armed conflict would threaten not only Chinese economic growth and the maintenance of the domestic social order, but the survival of the regime itself. To sustain these three pillars, Beijing needs a peaceful and stable international environment. During the present decade, the conditions above may be at stake. President Obama's "rebalancing strategy" to Asia-Pacific, for example, was perceived by China as increasing the United States' military presence in the region. With this, a nonAsian power still held the decisive role in organizing the balance of power in the region.

Similar to the American Rebalancing to Asia-Pacific, China's Strategy seeks to establish a major-country relation with the United States (CHINA, 2015). But today it seems that both China and the US have increasingly opposing projects to the region. In the realm 
China in the contemporary world order: grand strategy, military modernization... Augusto W. M. Teixeira Júnior • Peterson Ferreira da Silva

of geopolitics and geostrategy, the "Asia Rebalancing" and the "One Road, One Belt Initiative" are two opposing proposals to Asia and abroad (SINGH, 2016). Although President Trump ended the official US emphasis on the highly criticized Rebalancing Strategy, the ongoing trade war between the United States and China raises the tensions in East Asia (TWEED \& KOUTSOUKIS, 2018). Balance of power is thus a strong force shaping the regional strategic landscape.

\section{Final remarks}

In a broader political-economic context, the main driver of $\mathrm{Xi}$ Jinping's military reform becomes more comprehensive than securing modern armed forces, well-equipped, trained, and able to carry out full spectrum operations and missions. In general, PLA issues can be seen as a traditionally minefield for the country's leadership, owing to the historic role the military has achieved within the regime over decades, including assuming various non-combatant, bureaucratic, administrative, and commercial activities, especially under Deng Xiaoping's rule (BRANIGAN, 2015). It is possible to affirm, therefore, that the current reform of 2015 in PLA is marked more by the political character than the technical-military one. It is not merely a matter of securing more resources for the continuity of the main military projects under way, but rather of perfecting the organizational structures of China's armed forces and preparing them for the challenges of modern warfare. In this direction, $\mathrm{Xi}$ Jinping inserted the military issues on the radars of a comprehensive national anti-corruption campaign-which has served not only to ensure the political survival of the Communist Party, but also to consolidate the President's own leadership.

Moreover, it is important to note that China's institutional defense structure subordinates the military's role and attributions to civilian power-and the Central Military Commission (CMC) and 
China in the contemporary world order: grand strategy, military modernization... Augusto W. M. Teixeira Júnior • Peterson Ferreira da Silva

the Chinese Communist Party play a crucial role in this direction. Unlike in the Western tradition, in which civil-military separation exists as expressed in the classic thinking of authors such as Jomini and Clausewitz, the subordination of the military to civilian power in China clearly contrasts with the primacy of the Communist Party as the guiding agent of civil and military society.

Aside from domestic changes in defense structures and military modernization, the changing Asia-Pacific Strategic landscape is increasingly influenced by the major players in the region's Balance of Power. In some ways, China's fast development, and its military dimension, sparks responses from regional and global competitors. More important here than debating the probabilities of a future systemic war between Washington and Beijing, is to foresee how China might struggle to maintain the conditions that supports its transformations, while at the same time it emerges as a more important Asian power. In that sense, this paper makes it clear that military force has a growing role in China's grand strategy. But despite being a traditional expansionist rising power, military power is instrumental to Beijing's Peaceful Development. In other words, China's grand strategy clearly encompasses the centrality of military modernization in the country's growing international influence.

\section{References}

Allison, Grahan. Destined for War: can America and China escape thucydides's trap? New York: Houghton Mifflin Harcourt, 2017.

BLANCHARD, Ben. China's XI ASSUmes neW Role overseeIng MiLITARy Reform. Reuters, March 15, 2014. Available in: https://www.reUters.com/ ARTICLE/US-CHINA-DEFENCE/CHINAS-XI-ASSUMES-NEW-ROLE-OVERSEEING-MILITARY-REFORM-IDUSBREA2E05W20140315. ACCESSED on: 23 Feb. 2019. 
China in the contemporary world order: grand strategy, military modernization... Augusto W. M. Teixeira Júnior • Peterson Ferreira da Silva

Branigan, Tania. Politburo, army, casinos: China's Corruption Crackdown spreads. The Guardian, February 14, 2015. Available in: htTps:// WWW.THEGUARDIAN.COM/WORLD/2015/FEB/14/CHINA-CORRUPTION-CRACKDOWN-SPREADS-XI-JINPING. ACCESSED ON: 23 Feb. 2019.

BRZEZINSKI, Zbigniew. Strategic vision: America ANd the crisis of global POWER. NeW York: Basic BOOKS, 2013.

BUZAN, Barry. The Logic AND CONTRAdictions of 'PEACEFUl RISE/DEVELOPMENT' as China's grand strategy. The Chinese Journal of International Politics, v. 7, ISSUE 4, 2014. AvaILABLE IN: HTTPS://DOI.ORG/10.1093/cJIP/POU032. ACCESSED ON: 25 Feb. 2019.

CHASE, Michael S. et al. China's incomplete military transformation: assessing the Weaknesses of the People's Liberation Army (PLA). Santa Monica: Rand Corporation, 2015. Available in: httPs://www.rand.org/ CONTENT/DAM/RAND/PUBS/RESEARCH_REPORTS/RR800/RR893/RAND_RR893. PDF. ACCESSED ON: 23 FEB. 2019.

China, Information Office of the State Council. White Paper: China's Peaceful Development. People's Republic of China. September 2011. AVAILABLE IN: HTTP://ENGLISH.GOV.CN/ARCHIVE/WHITE_PAPER/2014/09/09/CONTENT_281474986284646.HTM. ACCESSED ON: 25 Feb. 2019.

China, Ministry of National Defense. China's Military Strategy. The State Council Information Office of the People's Republic of China. May 2015. Available In: htTP://Eng.MOd.gov.cn/Press/2015-05/26/CONTENT_4586805.HTM. ACCESSED on: 23 Feb. 2019.

Chinese army to raise military training standards. The People's Republico f China. Ministry of National Defense, Xinhua, March 20, 2014. Available IN: HTTP://ENG.MOD.GOV.CN/DEFENSENEWS/2014-03/20/CONTENT_4498796. htm\#. Accessed on: 23 Feb. 2019.

CHinese paper urges Pla Navy to build overseas military bases. Atlantic Council, China Defense Mashup. January 19, 2013. Available in: http:// 
China in the contemporary world order: grand strategy, military modernization... Augusto W. M. Teixeira Júnior • Peterson Ferreira da Silva

CHINA-DEFENSE-MASHUP.COM/CHINESE-PAPER-ADVISES-PLA-NAVY-TO-BUILD-OVERSEAS-MILITARY-BASES. HTML. AcCESSed on: 23 Feb. 2019.

ClauseWitz, Carl Von. On War (traduzido por Michael Howard e Peter PARet). OXford: Oxford University Press, 2007.

CLiFF, Roger. Anti-AcCess measures in Chinese defense strategy. RAND

Corporation. Testimony presented before the U.S. China Economic and Security Review Commission on January 27, 2011.

ECONOMIC and financial indicators. The Economist. World GDP, June 13TH, 2015. AVAILABLE IN: HTTPS://WWW.ECONOMIST.COM/ECONOMIC-AND-FINANCIAL-INDICATORS/2015/06/13/WORLD-GDP. ACCESSED ON: 23 FEB. 2019.

FACTS and figures on China's military reform. China Military, December 19, 2018. AvaILABLE IN: HTTP://ENG.CHINAMIL.COM.CN/VIEW/2017-12/19/CONTENT_7873713.HTM. ACCESSED on: 23 Feb. 2019.

IISS - International Institute for Strategic Studies. The Military Balance. LONDON: ROUTLEDGE, 2018.

JINPING, XI. SeCURE A deCISIVE VICTORY IN BUILDING A MOdeRATELY PROSPEROUS SOCIETY IN ALL RESPECTS AND STRIVE FOR THE GREAT SUCCESS OF SOCIALISM WITH Chinese characteristics for a new era. Full text of X I Jinping's Report at 19th CPC National Congress. October 18, 2017. Available in: http:// WWW.CHINADAILY.COM.CN/CHINA/19THCPCNATIONALCONGRESS/2017-11/04/CONTENT_34115212.htM. ACCESSED on: 23 Feb. 2019.

JOFFE, Ellis. 'People's War under Modern Conditions': a doctrine for modern war. The China Quarterly, n. 112, p. 555-571, Dec. 1987. Available IN: HTTPS://WWW.JSTOR.ORG/STABle/653779. AcCesSed on: 23 Feb. 2019.

Kaplan, Robert D. The Geography of Chinese Power. The New York Times, April 19, 2010. Available in: HTtPS://WwW.nYtimes. COM/2010/04/20/OPINION/20IHT-EDKAPLAN.HTML. ACCESSED ON: 19 MAY 2019. 
China in the contemporary world order: grand strategy, military modernization... Augusto W. M. Teixeira Júnior • Peterson Ferreira da Silva

KAPLAN, Robert D. The ReVenge of Geography: What the map tells about coming conflicts and the battle against fate. New York: Random House TRADE, 2013.

KOKOShin, Andrei A. 2015 Military reform in the People's Republica of China. Belfer Center for Science and International Affairs, Harvard Kennedy School, October 2016. Available in: https://www.belfercenter. ORG/PUBLICATION/2015-MILITARY-REFORM-PEOPLES-REPUBLIC-CHINA. ACCESSED ON: 23 FeB. 2019.

KROEBER, ARthur R. XI JinPING'S AMBITIOUS AgENDA FOR ECONOMIC REFORM IN China. Brookings, November 17, 2013. Available in: https://www.BrookINGS.EDU/OPINIONS/XI-JINPINGS-AMBITIOUS-AGENDA-FOR-ECONOMIC-REFORM-IN-CHInA/. Accessed on: 23 Feb. 2019.

LIANG, QiaO; XIANGSUI, Wang. Unrestricted Warfare. BejJing: PLA Literature and Arts Publishing House, February 1999.

LiU, Zhen. Here's What's behind the 'Nine-dash line' that SPARked the South China Sea conflict. Business Insider. Jul. 11, 2016. Available In: https:// WWW.BUSINESSINSIDER.COM/THE-NINE-DASH-LINE-AT-THE-HEART-OF-THE-SOUTH-CHINA-SEA-CONFLICT-2016-7. ACCESSEd ON: 23 Feb. 2019.

MCLANNAHAN, Ben. Goldman fund walks away from the Brics era. Financial Times, November 8, 2015. Avallable in: https://WwW.fT.com/ content/89f59acc-8679-11e5-8a12-b0ce506400Af. Accessed on: 23 Feb. 2019.

MCRAE, Hamish. By 2030, eCONOMies like ChinA ANd INDIA WILl hold DOMinANCE OVER WeSt - AND INFLUENCE OUR DECISIONS. INDEPENDENT, VoICES, SePtember 26, 2018. Available in: HTTPS://WWW.INDEPENDENT.CO.UK/VOICEs/ HSBC-ECONOMIES-CHINA-INDIA-EMERGING-WEST-EAST-TECHNOLOGY-A8556346. htMl. Accessed on: 23 Feb. 2019.

MEARSheimer, John J. Can China rise peacefully? National Interest, October 25, 2014. AvAILABLE IN: HTtPS://NATIONALINTEREST.ORG/COMMENTARY/ CAN-CHINA-RISE-PEACEFULLY-10204. AcCESSEd on: 23 Feb. 2019. 
China in the contemporary world order: grand strategy, military modernization... Augusto W. M. Teixeira Júnior • Peterson Ferreira da Silva

PETHIYAGODA, KadiRA. What'S DRIVING ChINA'S NEW SILK ROAD, AND HOW Should the West respond? Brookings, May 17, 2017. Available in: https:// WWW.BROOKINGS.EDU/BLOG/ORDER-FROM-CHAOS/2017/05/17/WHATS-DRIVINGCHINAS-NEW-SILK-ROAD-AND-HOW-SHOULD-THE-WEST-RESPOND/. ACCESSED ON: 19 MAY 2019.

Playing Chicken in the East China Sea. Center for Strategic and International Studies (CSIS), Asia Maritime Transparence InitiatiVe, ApriL 28, 2017. AVAILABLE IN: HTTPS://AMTI.CSIS.ORG/PLAYING-CHICKEN-EAST-CHINASEA/. ACCESSED ON: 23 FEB. 2019.

ROMANA, Heitor BarRas. Da CUltura estratéGica: uma ABordagem SISTÉmICa e interdisciplinar. Revista da Escola de Guerra Naval, Rio de Janeiro, v. 22, N. 1, P. 13-32, JAN./ABR. 2016.

SAUNDERS, Phillip C.; WUTHNOW, Joel. China's GoldWATer-Nichols? Assessing Pla organizational reforms. Joint Force Quarterly, 3rd quarTER, 82, JULY 1, 2016, P. 68-75. AVAILABLE IN: HTTP://NDUPRESS.NDU.EDU/ Media/News/Article/793267/ChinAS-GOldWATER-NICHOLS-ASSESSING-PLA-ORGANIZATIONAL-REFORMS/. ACCESSED ON: 23 Feb. 2019.

Sempa, Francis P. The geopolitical vision of Alfred Thayer Mahan. The Diplomat, December 30, 2014. Available in: https://thediplomat. COM/2014/12/THE-GEOPOLITICAL-VISION-OF-ALFRED-THAYER-MAHAN/. ACCESSED ON: 23 FeB. 2019.

SILVA, A. H. L.; TEIXEIRA JÚNIOR, Augusto W. M. Understanding Chinese and Indian balancing strategies. Revista da Escola de Guerra Naval (Ed. PORTUGUÊs), v. 22, P. 143-168, 2016.

SilVA, Peterson F. da. O debate sobre transformação militar na China: a Reforma de 2015 no Exército de Libertação Popular (PLA). Submitted to Centro de Estudos Estratégicos do Exército: Análise Estratégica, [S.d.].

SingH, Prashant Kumar. Changing contexts of Chinese military strategy and doctrine. IDSA Monograph Series, N. 49, MarCh 2016. 
China in the contemporary world order: grand strategy, military modernization... Augusto W. M. Teixeira Júnior • Peterson Ferreira da Silva

SLOAN, Elinor. Military transformation and MOdern warfare: A RefERence handbook. Westpor/London: Greenwood Publishing Group, 2008. TElXeira Júnior, Augusto W. M. Postura estratégica dos Estados Unidos e uso da força. Centro de Estudos Estratégicos do Exército: Análise Estratégica, [S.l.], v. 9, N. 3, P. 5-17, ago. 2018. Available in: HTTP://EBREVISTAS.EB.MIL.BR/INDEX.PHP/CEEEXAE/ARTICLE/VIEW/1636. ACCESSED ON: 23 FEB. 2019.

telXeira Júnior, Augusto W. M.. Grande EstratéGia e Modernização Militar da China Contemporânea. Submitted to Centro de Estudos Estratégicos do Exército: Análise EstratéGica, [S.l.].

TEIXEIRA JÚNIOR, Augusto W. M.; SOUZA, Valéria M.; CUNHA LEITE, AleXandre. Comparando estratéGIas de operacionalização de VARIÁVEIS EM RELAÇÕES INTERNACIONAIS: A MENSURAÇÃO DE CAPACIDADES DO PODER NACIONAL. Meridiano 47, 2017. Available In: hTtP://PeRIOdicos.unb.BR/OJs311/IndeX. PHP/MED/ARTICLE/VIEW/5313/4831. AcCESSED ON: 23 FEB. 2019.

TIAN, NAN Et AL. TRENDS IN WORLD MILITARY EXPENDITURE, 2018. SIPRI FACT Sheet, April 2019. Avallable IN; HTtPS://WwW.SIPRI.org/Sites/Default/ FILES/2019-04/FS_1904_MILEX_2018.PDF. ACCESSED ON: 19 MAY 2019.

TWEED, DAVIS; KOUTSOUKIS, JASON. U.S.-ChINA MILITARY TENSIONS START to rise as trade war deepens. Bloomberg, Politics, 26 de Setembro de 2018. AVAILABLE IN: HTTPS://WWW.BLOOMBERG.COM/NEWS/ARTICLES/2018-09-26/U-SCHINA-MILITARY-TENSIONS-START-TO-RISE-AS-TRADE-WAR-DEEPENS. ACCESSED ON: 23 FEB. 2019.

TWEED, David; LeUNG, Adrian. China is MAKING A Bold Military poWer Play. Bloomberg, May 7, 2018. Available In: htTPS://WWW.BloOMberg.com/ GRAPHICS/2018-ChINA-NAVY-BASES/. AcCesSED on: 23 Feb. 2019.

WUTHNOW, Joel; SAUNDERS, Phillip C. Chinese military Reforms In the age of Xi Jinping: drivers, challenges, and implications. China Strategic Perspectives, National Defense University (NDU), Institute for National 
China in the contemporary world order: grand strategy, military modernization... Augusto W. M. Teixeira Júnior • Peterson Ferreira da Silva

Strategic Studies (INSS), Center for the Study of Chinese Military Affairs, N. 10, March 2017. Available in: http://ndupress.ndu.edu/Media/NeWs/ ARTICLE/1125539/CHINESE-MILITARY-REFORMS-IN-THE-AGE-OF-XI-JINPING-DRIVERSCHALLENGES-AND-IMPLIC/. ACCESSED ON: 23 Feb. 2019.

YAO, KeVIn; BLANCHARD, Ben. China unveILS Boldest Reform In DECADES, Shows XI in command. Reuters, November 15, 2013. Available In: https:// WWW.REUTERS.COM/ARTICLE/US-CHINA-REFORM/CHINA-UNVEILS-BOLDEST-REFORMS-INDECADES-SHOWS-XI-IN-COMMAND-IDUSBRE9AEOBL20131115. ACCESSED ON: 23 Feв. 2019.

YOSHIDA, Reijo. Abe's Route to ReVising Article 9 crosses minefield of leGalese. The Japan Times, 2018. Available in: https://Www.JAPantimes.co.jp/ NEWS/2018/03/12/REFERENCE/ABES-ROUTE-REVISING-ARTICLE-9-CROSSES-MINEFIELD-LEgalese/\#.W8Oyg9dKiUk. Accessed on: 23 Feb. 2019.

ZeMin, Jiang. Speech by President Jiang Zemin of the people's Republic of China, at luncheon by the America China Society and five other organizations. October 30, 1997. Avallable In: htTPS://ASIASOCIETY.ORG/ SPEECH-PRESIDENT-JIANG-ZEMIN-PEOPLES-REPUBliC-CHINA. ACCESSED ON: 23 Feb. 2019. 